\title{
Professionalism Framings Across Medical Schools
}

\author{
Emma P. Deloughery, BS \\ Mayo Clinic School of Medicine, Rochester, MN, USA.
}

KEY WORDS: professionalism; medical education-professionalism; medical education-undergraduate.

J Gen Intern Med 33(5):610-1

DOI: $10.1007 / \mathrm{s} 11606-018-4314-0$

(c) Society of General Internal Medicine 2018

\section{INTRODUCTION}

Society has come to expect greater professionalism from its healthcare practitioners and trainees. Tangible outcomes associated with professionalism include improved patient satisfaction and reduced litigation risk, making increasing professionalism an important goal for training programs. ${ }^{1}$ However, defining a topic is necessary in order to effectively teach or evaluate that topic. ${ }^{2}$ A review of the medical education literature revealed that medicine lacks both a definition of professionalism and a consensus concept. ${ }^{3}$

Preliminary investigation into professionalism statements among various healthcare institutions found that statements could be encapsulated in one of seven key words that reflected the statement's framing of professionalism, as shown in Table 1. In the current study, the professionalism statements of the 144 Liaison Committee on Medical Education (LCME)accredited U.S. medical schools were examined to determine whether the framing of professionalism varied across medical schools, and whether differences existed based on geographic or institutional status (state-funded vs. private).

\section{METHODS}

The webpages and associated links for all 144 LCMEaccredited U.S. medical schools were searched for use of the word "professionalism." The links searched were, in descending order of priority, the medical school's homepage, the mission and values statement, and the student handbook. When "professionalism" was found on one page, the statement was categorized, without examining links of lower priority, as a best fit to one of seven framings of professionalism: Integrity, Behavior, Respect, Excellence, Business, Mixed, or Unclear. An eighth option, Absent, was used when a school's professionalism statement was unable to be located.

Following coding, the schools were divided into categories based on their geographic region using the divisions made by the U.S. Census Bureau, with Puerto Rican schools excluded from regional comparisons. Schools were also divided

Published online February 12, 2018 into state-funded and private categories. In addition, professionalism statements from the LCME and the Accreditation Council for Graduate Medical Education (ACGME) were coded.

\section{RESULTS}

Professionalism statements were found for $89.6 \%$ of medical schools. As displayed in Table 2, the Integrity category encompassed the most statements $(36.1 \%)$, followed by

Table 1 Definitions and Examples of Professionalism Framings

\begin{tabular}{|c|c|c|}
\hline Category & Definition & Example \\
\hline Integrity & $\begin{array}{l}\text { Honesty, accountability, } \\
\text { responsibility }\end{array}$ & $\begin{array}{l}\text { "Ethical behavior, } \\
\text { professionalism and } \\
\text { integrity are required of } \\
\text { every student"- University } \\
\text { of Arizona College of } \\
\text { Medicine-Phoenix }\end{array}$ \\
\hline Behavior & $\begin{array}{l}\text { Employee/student/ } \\
\text { volunteer actions, dress, } \\
\text { or attitudes }\end{array}$ & $\begin{array}{l}\text { "Failure to attend or } \\
\text { repeated tardiness is a } \\
\text { failure of professionalism" } \\
\text { Case Western Reserve } \\
\text { University School of } \\
\text { Medicine }\end{array}$ \\
\hline Respect & $\begin{array}{l}\text { Compassion, diversity, } \\
\text { collaboration }\end{array}$ & $\begin{array}{l}\text { "Professionalism: } \\
\text { Maintaining a respectful } \\
\text { institution" - University of } \\
\text { Nevada, Reno School of } \\
\text { Medicine }\end{array}$ \\
\hline Excellence & $\begin{array}{l}\text { Patient care, outcomes, } \\
\text { rankings }\end{array}$ & $\begin{array}{l}\text { "Standards of academic } \\
\text { achievement, clinical ability } \\
\text { and professionalism are } \\
\text { high" - Albert Einstein } \\
\text { College of Medicine }\end{array}$ \\
\hline Business & $\begin{array}{l}\text { Financial, marketing, or } \\
\text { customer service } \\
\text { concerns }\end{array}$ & $\begin{array}{l}\text { "To ensure quality services } \\
\text { and professionalism, we } \\
\text { strive: to operate sound } \\
\text { management principles...to } \\
\text { vigilantly guard and manage } \\
\text { our resources...to foster } \\
\text { training and growth in } \\
\text { skills" - St. Joseph Health } \\
\text { Mission Hospital }\end{array}$ \\
\hline Mixed & $\begin{array}{l}\text { A mixture of two of the } \\
\text { above framings }\end{array}$ & $\begin{array}{l}\text { "[Y]ou not only represent } \\
\text { but also model these values } \\
\text { of professionalism - } \\
\text { compassion, integrity, } \\
\text { respect, and collaboration" - } \\
\text { University of Texas Medical } \\
\text { School Health Science } \\
\text { Center at Houston }\end{array}$ \\
\hline Unclear & $\begin{array}{l}\text { Either a mixture of more } \\
\text { than two of the above } \\
\text { framings or a lack of } \\
\text { definition or explanatory } \\
\text { context }\end{array}$ & $\begin{array}{l}\text { "Fosters and assesses the } \\
\text { skills, knowledge, and } \\
\text { professionalism of students } \\
\text { necessary for success" - } \\
\text { Uniformed Services } \\
\text { University }\end{array}$ \\
\hline
\end{tabular}


Table 2 Distribution of Professionalism Framings among All Schools and by Geographic Region and State-Funded vs. Private Status

\begin{tabular}{|c|c|c|c|c|c|c|c|}
\hline & All schools & Northeast & South & Midwest & West & State-funded & Private \\
\hline Integrity & $52(36.1 \%)$ & $15(45.5 \%)$ & $18(34.0 \%)$ & $12(34.3 \%)$ & $6(31.6 \%)$ & $32(35.6 \%)$ & $20(37.0 \%)$ \\
\hline Behavior & $15(10.4 \%)$ & $1(3.0 \%)$ & $3(5.7 \%)$ & $9(25.7 \%)$ & $2(10.5 \%)$ & $10(11.1 \%)$ & $5(9.3 \%)$ \\
\hline Respect & $9(6.3 \%)$ & $4(12.1 \%)$ & $2(3.8 \%)$ & $1(2.9 \%)$ & $2(10.5 \%)$ & $5(5.6 \%)$ & $4(7.4 \%)$ \\
\hline Excellence & $8(5.6 \%)$ & $2(6.1 \%)$ & $2(3.8 \%)$ & $2(5.7 \%)$ & $2(10.5 \%)$ & $6(6.7 \%)$ & $2(3.7 \%)$ \\
\hline Mixed & $17(11.8 \%)$ & $3(9.1 \%)$ & $9(17.0 \%)$ & $2(5.7 \%)$ & $3(15.8 \%)$ & $13(14.4 \%)$ & $4(7.4 \%)$ \\
\hline Unclear & $28(19.4 \%)$ & $4(12.1 \%)$ & $11(20.8 \%)$ & $8(22.9 \%)$ & $2(10.5 \%)$ & $18(20.0 \%)$ & $10(18.5 \%)$ \\
\hline Absent & $15(10.4 \%)$ & $4(12.1 \%)$ & $8(15.1 \%)$ & $1(2.9 \%)$ & $2(10.5 \%)$ & $6(6.7 \%)$ & $9(16.7 \%)$ \\
\hline Total & 144 & 33 & 53 & 35 & 19 & 90 & 54 \\
\hline
\end{tabular}

Unclear, Mixed, Behavior, Absent, Respect, and Excellence. No medical school had a Business framing.

Integrity remained the most popular framing among all geographic regions. The Midwest had the highest proportion of schools with Behavior and Unclear framings, the Northeast the most Respect framings, the West the most Excellence framings, and the South the most Mixed and Absent framings.

No substantive differences were seen between state-funded and private schools. State schools had slightly higher Excellence and Mixed framings. Private schools more often lacked a framing.

\section{DISCUSSION}

There is a strong focus on the teaching of professionalism in medical school, but little data on how medical schools themselves view professionalism. ${ }^{4}$ This study found that although Integrity is the most popular framing of professionalism among medical schools, it is far from the only one.

A major problem with multiple framings of professionalism arises when comparing medical school framings with those of accreditation bodies. In its Functions and Structure of a Medical School for 2017-18, the LCME states that "[a] medical school ensures that the learning environment of its medical education program is conducive to the ongoing development of explicit and appropriate professional behaviors in its medical students," ${ }^{5}$ which indicates a Behavior-based framing. In contrast, the ACGME's Global Resident Competency Rating Form includes under the Professionalism category that the resident "Demonstrates integrity and ethical behavior; accepts responsibility and follows through on tasks", ${ }^{6}$ suggesting an alignment of professionalism with Integrity. That the LCME emphasizes Behavior while the ACGME focuses on Integrity suggests a clash not only between the majority of medical schools and their accreditation body, but also between the physician's learning and training environments.
Given the diversity of professionalism statements across medical schools and accreditation bodies, it seems possible that a consensus framing of professionalism does not exist within medicine at all. With the sharp differences among schools and the general lack of agreement between schools and the LCME and ACGME, it would seem unwise to place too great an emphasis on the assessment of a medical student's or resident's "professionalism," and it may even be best to avoid using the word in statements and evaluations, given that it means very different things to different institutions and people.

Acknowledgements: Thanks to Frederic W. Hafferty for his advice on project design and editing of the manuscript. This manuscript was presented at the April 2017 meeting of the Academy for Professionalism in Health Care in Chicago, IL, and at the April 2017 AAMC CGSA/COSR Regional Meeting in Rochester, MN.

Corresponding Author: Emma P. DeLoughery, BS; Mayo Clinic School of Medicine, Rochester, MN, USA (e-mail: deloughery. emma@mayo.edu).

\section{Compliance with Ethical Standards:}

Conflict of Interest: The author has no conflicts of interest.

\section{REFERENCES}

1. Mueller PS. Teaching and assessing professionalism in medical learners and practicing physicians. Rambam Maimonides Med J. 2015;6(2):e0011.

2. Cruess SR, Cruess RL. Teaching professionalism - Why, What and How. Facts Views Vis ObGyn. 2012;4(4):259-65.

3. Birden H, Glass N, Wilson I, Harrison M, Usherwood T, Nass D. Defining professionalism in medical education: a systematic review. Med Teach. 2014;36(1):47-61

4. Goldstein EA, Maestas RR, Fryer-Edwards K, et al. Professionalism in medical education: an institutional challenge. Acad Med. 2006;81(10):871-6.

5. Liaison Committee on Medical Education. Standards, publications, \& notification forms. 2016. http://lcme.org/publications/. Accessed 12 October 2017.

6. Summative evaluation of competencies for 12-month clinical phase residents. http://www.acgme.org/Portals/0/PFAssets / ProgramResources/380_SummativeEvaluation_GPM_AA_04_10_2008. pdf. Accessed 12 October 2017. 